\title{
VEGETATIVE PROPAGATION OF Spondias tuberosa E Spondias dulcis WITH THE USE OF IMMERSION IN INDOLE ACETIC ACID ${ }^{1}$
}

\author{
GABRIELA TEODORO ROCHA ${ }^{2}$, AYURE GOMES DA SILVA ${ }^{3}$, JULIANA BEZERRA MARTINS ${ }^{4}$, NEI PEIXOTO ${ }^{5}$,
} FABRICIO RODRIGUES ${ }^{5}$

\begin{abstract}
The objective of this work was to evaluate the effect of six indole-3-acetic acid (IAA) concentrations and three immersion times in IAA solutions on the vegetative propagation of Spondias dulcis and Spondias tuberosa by stem cuttings. The experiment was conducted in a greenhouse, using a completely randomized design, with a $6 \times 3$ factorial arrangement consisting of six indole-3-acetic acid concentrations $(0,2$, $4,6,8$, and $\left.10 \mathrm{~g} \mathrm{~L}^{-1}\right)$ and three immersion times $(8,16$, and 24 seconds), with ten cuttings of $S$. dulcis and $S$. tuberosa per plot, and three replications. Percentage of surviving cuttings, and percentage of rooted cuttings, number of leaf buds, number of roots per cutting, root length, and total fresh weight were evaluated at 180 days after planting. Data were subjected to analysis of variance by the F test and to regression analysis. Vegetative propagation from woody cuttings of $S$. dulcis is not viable to produce seedlings, thus, new studies on this technique for this species are needed. Vegetative propagation from woody cuttings of $S$. tuberosa is satisfactory, but with low efficiency for improvement and emergence of new shoots and roots; it is more effective when using a concentration of $10 \mathrm{~g} \mathrm{~L}^{-1}$ of indole-3-acetic acid and immersion time in the solution of 16 seconds.
\end{abstract}

Keywords: Plant growth regulator. Fruit trees. Umbu. Cajá-manga.

\section{PROPAGAÇÃO VEGETATIVA DE Spondias tuberosa E Spondias dulcis COM O USO DE IMERSÃO EM ÁCIDO INDOL ACÉTICO}

RESUMO - O objetivo deste trabalho foi avaliar o efeito de seis concentrações do ácido indol-3-acético (AIA), em três tempos de imersão em soluções de AIA, na propagação vegetativa por estaquia de Spondias dulcis e Spondias tuberosa. O experimento foi conduzido em delineamento experimental inteiramente causalizados, em esquema fatorial ( 6 x 3), em seis concentrações $\left(0,2,4,6,8\right.$ e $\left.10 \mathrm{~g} \mathrm{~L}^{-1}\right)$ do AIA e três intervalos de imersão (8, 16 e 24 segundos), com dez estacas por parcela de $S$. dulcis e $S$. tuberosa, com três repetições, em casa de vegetação. A porcentagem de sobrevivência das estacas, porcentagem de estacas enraizadas, número de brotações jovens foliares, número de raízes por estacas, comprimento geral das raízes e massa fresca total foram avaliadas aos 180 dias após o plantio. Os dados foram submetidos à análise de variância pelo teste de $\mathrm{F} \mathrm{e}$ ajustados em equações de regressão. Concluiu-se que a propagação vegetativa na espécie Spondias dulcis não obteve resultados satisfatórios utilizando a técnica proposta no trabalho. Concluiu-se, também, que a técnica de propagação vegetativa na espécie Spondias tuberosa obteve resultados satisfatórios, porém, com pouca eficiência para o aumento e emergência de novos brotos e raízes, e mais efetiva na concentração $10 \mathrm{~g} \mathrm{~L}^{-1} \mathrm{de}$ AIA, com 16 segundos de imersão.

Palavras-chave: Regulador vegetal. Frutíferas. Umbu. Cajá-manga.

\footnotetext{
${ }^{*}$ Corresponding author

${ }^{1}$ Received for publication in 02/06/2018; accepted in 09/09/2019.

Paper extracted from dissertation of the first author.

${ }^{2}$ Department of Genetic Resources and Biotechnology, Universidade de Brasília, Brasilia, DF, Brazil; gabriela_teodoro.rocha@yahoo.com.br - ORCID: 0000-0001-7313-8922.

${ }^{3}$ Department of agriculture, Faculdade Evangélica de Goianésia, Goianésia, GO, Brazil; ayuregomes@gmail.com - ORCID: 0000-00017228-1989.

${ }^{4}$ Department of plant Breeding, Universidade Federal de Goiás, Goiânia, GO, Brazil; juliana_agro26@hotmail.com - ORCID: 0000-00026291-8912.

${ }^{5}$ Department of plant Breeding, Universidade Estadual de Goiás, Ipameri, GO, Brazil; nei.peixoto48@gmail.com - ORCID: 0000-00032319-8139, fabricio.rodrigues@ueg.br - ORCID: 0000-0002-6133-6363.
} 


\section{INTRODUCTION}

The Anacardiaceae family comprises approximately 70 genera with 875 species that are found in temperate, tropical, and subtropical regions worldwide (ALBUQUERQUE et al., 2015). Several species of this family are economically important because they produce edible fruits of distinct appearance, with a taste that please consumers (ROCHA et al., 2015).

The Spondias genus belongs to this family, in the subfamily Spondioideae (MITCHELL, DALY, 2015). It comprises approximately 18 species; seven of which are found in the Americas (SILVA et al., 2014), and approximately ten are found in Asia (SANTOS; OLIVEIRA, 2008).

Spondias tuberosa Arruda Câmara is a tropical, xerophytic fruit species that is indigenous to the semiarid plateaus of the Northeast region of Brazil (LIMA et al., 2015). Plants of this tree species are hermaphrodite and can reach heights of approximately $10 \mathrm{~m}$ and diameter at breast height (DBH) of up to $41 \mathrm{~cm}$; they have dense, low, tortuous structures with broad crown and tuberous roots (MITCHELL; DALY, 2015). This species has good adaptability to regions with long periods of drought because it has a mechanism of defense against water deficit-alteration of its roots into xylopodia to store water, minerals, and sugars for the survival of the plant during these periods (LINSNETO et al., 2012; ANTUNES et al., 2016).

$S$. tuberosa is an important fruit species because it can be grown in large scale in agroforestry systems, and for reforestation or human consumption (SANTOS; OLIVEIRA., 2008; ANDRADE et al., 2013).

Spondias dulcis Parkinson is another important commercial species in Brazil, because it is easy to grow, and produces fruits that has good acceptance by consumers due to its pleasant flavor and aroma. Plants of this tree species are hermaphrodite and can reach a height of $25 \mathrm{~m}$ and a DBH of $40 \mathrm{~cm}$ (LORENZI, 2006; MITCHELL; DALY, 2015); its fruits have ellipsoidal shape, and juicy and slightly acidic flesh when ripe; and its seeds are fibrous and have a rigid thorny structure (VANZELA et al., 2011).

However, the lack of availability of seeds and technical information are obstacles to commercial crops of native fruit species, especially Spondias spp. $S$. tuberosa has asexual and seed propagation; seed propagation has extremely slow development, with fruit production only after 10 years, making commercial orchards unviable (REIS et al., 2010). S. dulcis is also propagated by seeds, presenting slow and uneven development, which is undesirable for commercial plantations (SANTOS et al., 2010).

Auxins are the most used growth regulator to improve propagation processes of fruit plants from stem cuttings by stimulating formation of secondary roots, root nodules, and bud emergence. However, the results may vary according to the species, abiotic factors, fruiting and flowering season of the species, cutting type, application mode of the plant growth regulator hormone, and substrate used (OINAM et al., 2011).

In this context, the objective of this work was to evaluate the effect of six indole-3-acetic acid (IAA) concentrations and three immersion times in IAA solutions on the vegetative propagation of Spondias dulcis and Spondias tuberosa stem cuttings.

\section{MATERIAL AND METHODS}

The experiment was conducted in a greenhouse with height of $3.5 \mathrm{~m}$, length of $30 \mathrm{~m}$, and width of $7 \mathrm{~m}$, covered with a 150-micron light diffusing polyethylene film and a 50\% shade screen, at the Goiás State University (UEG), Ipameri campus, GO, Brazil.

The cuttings were collected from plants that were at the end of the vegetative rest stage (leafless and with swollen buds); they were manually defoliated and cut with a straight cut at the top and a diagonal cut at the base using pruning shears; the cuttings used had length of $20 \mathrm{~cm}$ and approximately $2 \mathrm{~cm}$ in diameter, and at least two lateral buds. (SOUZA; COSTA, 2010).

The Spondias tuberosa cuttings were collected from adult plants at the Akenaton Farm $\left(17^{\circ} 39^{\prime} 10.92^{\prime \prime S}, 48^{\circ} 1^{\prime} 52.3^{\prime \prime} \mathrm{W}\right.$, altitude of $\left.815 \mathrm{~m}\right)$, in Ipameri. The Spondias dulcis cuttings were collected from adult plants at the UEG Experimental Farm in May, 2016. The temperature of the southwestern state of Goiás ranged from $16{ }^{\circ} \mathrm{C}$ (night) to $27{ }^{\circ} \mathrm{C}$ (daytime) during the winter (dry season) and early summer (rainy season).

The experiment was conducted in a completely randomized design with three replications, using a $6 \times 3$ factorial arrangement consisting of six indole-3-acetic acid (IAA) concentrations $\left(0,2,4,6,8\right.$, and $\left.10 \mathrm{~g} \mathrm{~L}^{-1}\right)$ and three immersion times $(8,16$, and 24 seconds), with ten cuttings per plot.

The concentrations of indole-3-acetic acid (IAA) $\mathrm{C}_{10} \mathrm{H}_{9} \mathrm{NO}_{2}$, MW $175.18,99 \%$ purity were reached by dilutions in an ethyl alcohol-distilled water solution (1:1) (SOUZA; COSTA, 2010). The cuttings were immersed for 8,16 , or 24 seconds in the different IAA concentrations and placed in 12liter polypropylene pots filled with a subtract composed of dystrophic Red Latosol (Oxisol) (SANTOS, 2018). The soil acidity was corrected with dolomitic limestone (total neutralizing power of $70 \%$ ) at 28 days before the experiment implementation, then, irrigations were performed every two days. Soil fertilization consisted of six grams of N-P-K (8-28-16), according to the following soil chemical characteristics: $\mathrm{pH}$ of 4.9 , 
$24.1 \mathrm{~g} \mathrm{dm}^{-3}$ of organic matter, $5 \mathrm{mg} \mathrm{dm}^{-3}$ of $\mathrm{P}, 30.3$ $\mathrm{mmol}_{\mathrm{c}} \mathrm{dm}^{-3}$ of $\mathrm{H}+\mathrm{Al}, 4.1 \mathrm{mmol}_{\mathrm{c}} \mathrm{dm}^{-3}$ of $\mathrm{K}, 18.2$ $\mathrm{mmol}_{\mathrm{c}} \mathrm{dm}^{-3}$ of $\mathrm{Ca}, 7.5 \mathrm{mmol}_{\mathrm{c}} \mathrm{dm}^{-3}$ of $\mathrm{Mg}$, sum of bases of $27.8 \mathrm{mmol}_{\mathrm{c}} \mathrm{dm}^{-3}$, CEC of $57.6 \mathrm{mmol}_{\mathrm{c}} \mathrm{dm}^{-3}$, and base saturation (\%) of 47.7 .

Cylindrical structures of 1-meter height were made with bamboo and twine and covered with light diffuser polyethylene bags (40 microns) to avoid the soil of the pots to dry, and to maintain a high air humidity for cutting propagation. The experiment last 180 days (from May to November) and was divided into two stages: the first consisted of maintaining the pots with the cuttings in a transparent plastic container for 90 days to protect them and keep the air humidity; and the second consisted of maintaining them without this protection for another 90 days. Irrigations were carried out using $500 \mathrm{ml}$ of water every four days in the first stage, and every two days in the second.

The evaluations performed were: percentage of surviving cuttings (CSP), in which the surviving cuttings that presented live wood, buds, or rooting were considered for counting, and, subsequently, transformed into percentages; rooted cutting percentage $(\mathrm{RCP})$, considering the cuttings with induction of radical primordia with at least $1 \mathrm{~mm}$ as rooted and, subsequently, transformed into percentages; number of roots per cutting (NRC), it was counted and summed the number of roots already formed, longer than $1 \mathrm{~mm}$; root length (RL), all roots emitted by the cuttings were measured with the aid of a ruler; number of leaf buds (NLB), the total number of buds per cutting was counted and, subsequently, an average per cutting was attributed; and total fresh weight (TFW), the total weight of roots, leaves, and buds were weighted and summed in a precision balance.

The data were subjected to analysis of variance, and fitted to regression equations, according to the significant equation, for the different IAA concentrations as a function of immersion times for the two species, using the SISVAR 5.0 software (FERREIRA, 2011).

\section{RESULTS AND DISCUSSION}

No satisfactory results were found for the vegetative propagation of Spondias dulcis; the method used for the stem cuttings had no benefits to rooting and sprouting, resulting in rotting of vegetative propagules with the different indole acetic acid (AIA) concentrations and cutting immersion times used and, in some cases, malformation of roots and leaves. Thus, some changes should be done in the procedure adopted to result in cuttings with absence of pathogens and with a greater possibility of seedling formation.

According to Souza and Costa (2010), branches of $S$. dulcis should be removed after a vegetative rest for asexual propagation, i.e., when they are defoliated and with large buds. In addition, Souza and Araújo (1999) stated that the collection season of propagules should be carried out at the end of the phenological stage of the species, i.e., a few days before the emergence of new leaves and flowers. In the present study, the collections for this species were carried out when the plants were at the vegetative rest stage, but no positive results were found, thus, confirming the need for further studies about vegetative propagation of $S$. dulci.

Root development in cuttings is affected by physiological conditions of the plant and conditions of the environment in which they are propagated (FACHINELLO; HOFFMANN; NACHTIGAL, 2005). The cuttings used was maintained under the humidification structure for 90 days; thus, the substrate moisture, air temperature, and permanence time could have affected negatively the rooting of the cuttings, and shorter periods could generate better results. In addition, environmental factors are related to the time of the year in which the cuttings are collected; cutting consistency, root formation potential, and survival are affected at unfavorable times. Thus, more tests should be performed considering different times of collection of cuttings to find an alternative for commercial production of this species.

Substrate moisture also affects the cutting propagation; low-moisture substrates can reduce infection by pathogens and cutting rotting (SOUZA; COSTA, 2010). The soil used for the substratedystrophic red Latosol (Oxisol) has a large proportion of sand, but it remained with a high moisture. According to Nachtigal (1999), the death of vegetative propagules during the rooting process can be associated with the occurrence of pathogens that cause rotting of the cutting, and with absence of new root formation by exhausting the cutting nutrient reserves, resulting in the loss of vegetative material.

Spondias tuberosa presented satisfactory results, with a significant effect for all sources of variation and variables (Table 1). Paula et al. (2007) found similar results, with significant effect of indole -3-butyric acid (IBA) concentrations $\left(0\right.$ to $\left.2 \mathrm{~g} \mathrm{~L}^{-1}\right)$ on percentage of survival and rooting of $S$. tuberosa. However, Almeida et al. (2017) evaluated 15 variables of cuttings of Spondias sp. subjected to treatments with IBA ( 0 to $\left.2.4 \mathrm{~g} \mathrm{~L}^{-1}\right)$ and found significance only for the number of buds with the application of IBA. 
Table 1. Mean squares of percentage of surviving cuttings (PSC), percentage of rooted cuttings (PRC), number of leaf buds (NLB), number of roots per cutting (NRC), root length (RL), and total fresh weight (TFW) of Spondias tuberosa subjected to different immersion times (seconds) in different indole-acetic acid (IAA) concentrations.

\begin{tabular}{cccccccc}
\hline SV & DF & PSC & PRC & NLB & NRC & GRL & TFW \\
\hline Time (T) & 2 & $61.76^{* *}$ & $485.71^{* *}$ & $5.74^{* *}$ & $1.34^{* *}$ & $139.05^{* *}$ & $889.99^{* *}$ \\
Concentrations (C) & 5 & $105.56^{* *}$ & $35.58^{* *}$ & $0.08^{*}$ & $0.26^{* *}$ & $30.49^{* *}$ & $190.39^{* *}$ \\
Tempo*Concentração & 10 & $17.47^{*}$ & $33.25^{*}$ & $5.03^{* *}$ & $1.01^{*}$ & $31.46^{*}$ & $144.79^{* *}$ \\
erro & 108 & 04.98 & 2.97 & 0.02 & 0.01 & 2.33 & 21.86 \\
\hline CV (\%) & & 15.79 & 23.92 & 5.82 & 5.82 & 11.80 & 31.19 \\
\hline
\end{tabular}

$\mathrm{SV}=$ source of variation; $\mathrm{DF}=$ degree of freedom; $\mathrm{CV}=$ coefficient of variation; $* *=$ significant at $1 \%$ and $*=$ significant at $5 \%$ probability by the $\mathrm{F}$ test.

Figure 1A shows the quadratic regression curves found for percentage of surviving cuttings as a function of IAA concentrations $\left(0\right.$ to $\left.10 \mathrm{~g} \mathrm{~L}^{-1}\right)$ in all immersion times used. There is also a $44 \%$ increase in the percentage of surviving cuttings in $S$. tuberosa, on average, in the three immersion times, considering the first and final points of the equations, demonstrating that as it is increased, the cutting survival rates increase. The maximum range points in the equations at immersion times of 8,16 , and 24 seconds were 7.0, 9.1, and $9.8 \mathrm{~g} \mathrm{~L}^{-1}$, respectively; from these points, the increase would no longer be viable.

Vignolo et al. (2012) tested IBA concentrations $\left(0\right.$ to $\left.6 \mathrm{~g} \mathrm{~L}^{-1}\right)$ in three blueberry (Vaccinium ashei Read) cultivars using a ten-second immersion period and found an increase in surviving cutting of $25 \%$, with linear increases as the concentrations of the growth regulator were increased. The use of high levels of auxins stimulates secondary root formation, which are important for the vegetative propagation of cuttings (TAIZ; ZEIGER, 2009); thus, the highest concentrations of IAA satisfactorily promoted root system development of the $S$. tuberosa cuttings, increasing percentage of surviving cuttings.

Contrastingly, Pereira et al. (2017) found lower survival percentage of cuttings of Sequoia sempervirens (D. Don) Endl. when using high levels of IBA, even with reapplication in different periods, reaching the lowest survival percentage when using concentrations of 3 and $6 \mathrm{~g} \mathrm{~L}^{-1}$ and 15 seconds of immersion. This indicates that the application of this growth regulator does not improve this variable. Cutting survival of $S$. tuberosa increased when using high IAA concentrations and the longest immersion times; thus, auxin affects positively the survival and rooting of cuttings, with possible stabilization when using high concentrations (Figure 1A).

The percentage of rooted cuttings presented a linear growth when using immersion time of 16 seconds; the mean increase in percentage of rooted cuttings between the 0 and $10 \mathrm{~g} \mathrm{~L}^{-1}$ concentrations was $25 \%$ (Figure 1B). The lowest percentage of rooted cuttings were found when using immersion times of 8 and 24 seconds ( 4.5 and $3.7 \mathrm{~g} \mathrm{~L}^{-1}$, respectively), with increases of $61 \%$ and $46 \%$, respectively, as the IAA concentration were increased from these points. This confirms the benefits of using high concentrations of auxins for secondary root formation of $S$. tuberosa.

Increases in the percentage of rooted cuttings may be connected to the sufficient auxin levels in their tissues, which promote the formation of new roots, favoring the initial development of seedlings (PIO et al., 2007). Therefore, the use of growth regulator combined with the plant auxin contents may have affected the rooting capacity of $S$. tuberosa propagules; however, the auxin contents in the cuttings were probably sufficient to promote formation of secondary roots.

The highest percentage of rooted cuttings $(11 \%)$ was found with the IAA concentration of $10 \mathrm{~g}$ $\mathrm{L}^{-1}$ in the immersion time of 16 seconds; and the lowest with the lowest (2\%) immersion time and IAA concentration of $4 \mathrm{~g} \mathrm{~L}^{-1}$ (Figure 1B). Despite the positive results with the application of IAA, the percentages were low and, thus, the benefits of using this technique are limited. Atroch, Cravo, Santos (2007) evaluated cuttings of Paullinia cupana var. Sorbilis under the same concentrations used for the $S$. tuberosa and found relatively lower percentages of rooted cuttings at high IBA concentrations; the lowest $(7 \%)$ was found in the treatment with IBA concentration of $10 \mathrm{~g} \mathrm{~L}^{-1}$, and the highest $(8 \%)$ in the control treatment, thus, in this case, the use of IBA was not a viable technique. IAA has less effect than other auxins used for vegetative propagation and induces greater root formation when used at high concentrations, whereas the IBA and 1Naphthaleneacetic acid (NAA) induce greater root formation when used at low concentrations (RADMANN; FACHINELLO; PETERS, 2002). 

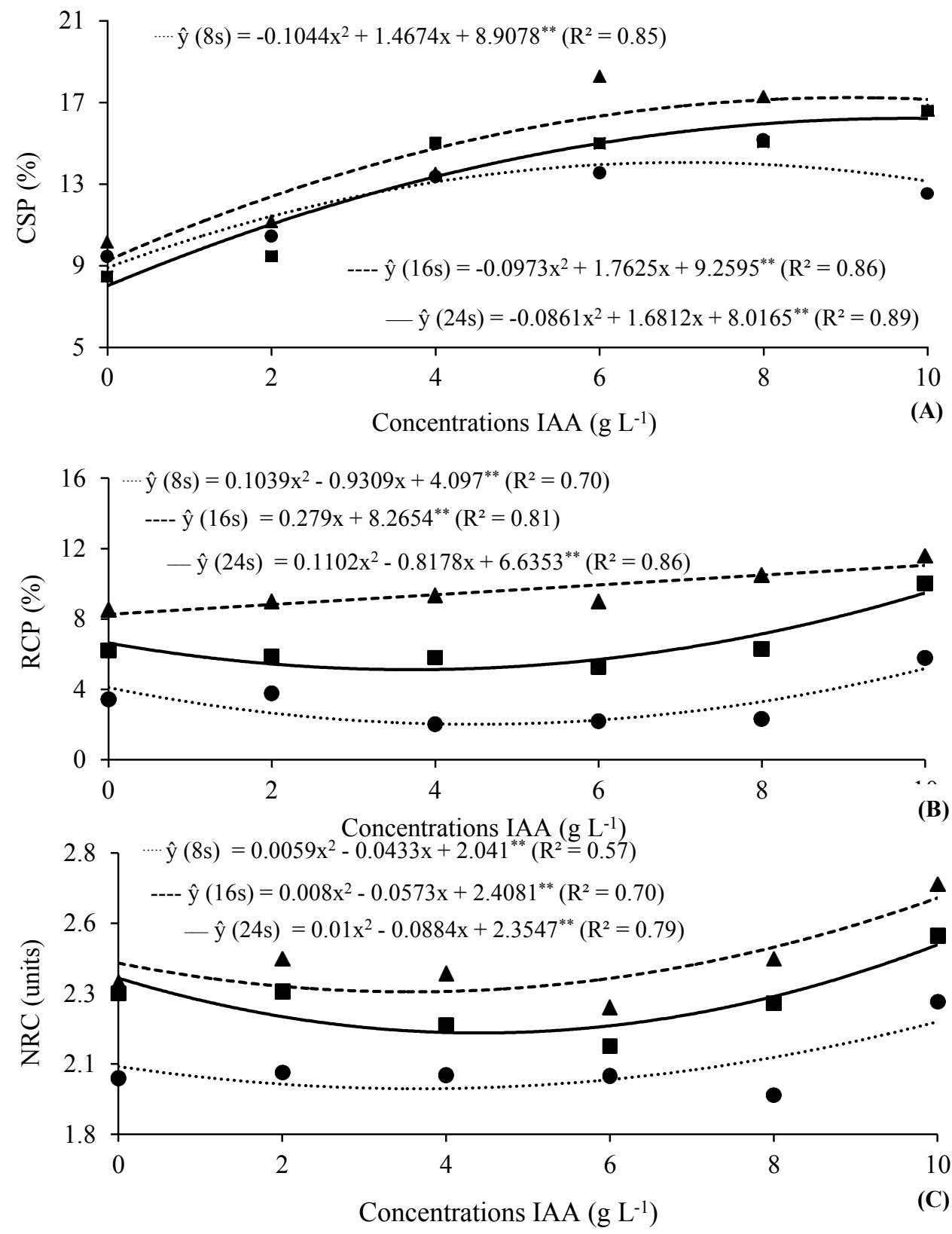

Figure 1. Regression analysis for percentage of surviving cuttings (PSC - A), percentage of rooted cuttings (PRC - B), and number of roots per cutting (NRC - C) of Spondias tuberosa.

The number of roots per cutting had a small increase with increasing IAA concentrations (Figure $1 C$ ), present increases of approximately $7 \%, 5 \%$, and $9 \%$ with immersion times of 8,16 , and 24 seconds, respectively, at the highest IAA concentration when compared to the control treatment. These increases may improve vegetative propagation of $S$. tuberosa cuttings for commercial plantations, since they improve water and nutrient absorption by cuttings, resulting in a greater number of rooted and surviving propagules. The viability of vegetative propagation depends on the secondary root formation capacity and root system quality of the plant used for propagation, which affects plant nutrition and survival, mainly of species with asexual propagation (FACHINELLO; HOFFMANN; NACHTIGAL,
2005).

The lowest estimated numbers of roots per cutting were found with the concentration of $3.8 \mathrm{~g} \mathrm{~L}$ ${ }^{1}$ (Figure 1C), presenting mean increases of $12.3 \%$ per increased unit of IAA after this point. The highest number of roots per cutting (2.5) was found when using an IAA concentration of $10 \mathrm{~g} \mathrm{~L}^{-1}$ and immersion time of 16 seconds; and the lowest (2) when using an IAA concentration of $4 \mathrm{~g} \mathrm{~L}^{-1}$ and immersion time of 8 seconds, presenting little increase as the IAA concentrations were increased. According to Fischer et al. (2008), phytoregulators affect the development of secondary roots, promoting or inhibiting the rooting process; thus, the use of the control treatment presented practical advantages with reduced costs for the process. 
Rios et al. (2012) evaluated cuttings of $S$. tuberosa subjected to different IBA concentrations and found a linear growth as the concentrations were increased, presenting mean increases of $20 \%$ in the number of roots, percentage of rooted cuttings, and number of roots per cutting from 0 to $6 \mathrm{~g} \mathrm{~L}^{-1}$. However, Chalfun et al. (2007) evaluated the use of IBA on Cydonia oblonga L cuttings and found the highest number of roots per cutting (approximately 4.7 units) when using a concentration of $1.4 \mathrm{~g} \mathrm{~L}^{-1}$, with decreases after this point.

Root growth stimulation depends on several factors, mainly auxin concentration; an adequate supply of auxin can increase secondary root formation, generating seedlings with improved adaptive capacity and resistant to climatic variations (OLIVEIRA et al., 2015)

The lowest root lengths of the cuttings were found when using the concentrations of 4.1, 4.5 and $4.1 \mathrm{~g} \mathrm{~L}^{-1}$, with increases after these points, denoting that the use of IAA was beneficial to the cuttings, despite the low increases found (Figure 2A). The mean increase of $1.21 \mathrm{~mm}(9 \%)$ found when using the concentration of $10 \mathrm{~g} \mathrm{~L}^{-1}$ generated a greater adaptive advantage for the treated $S$. tuberosa cuttings.
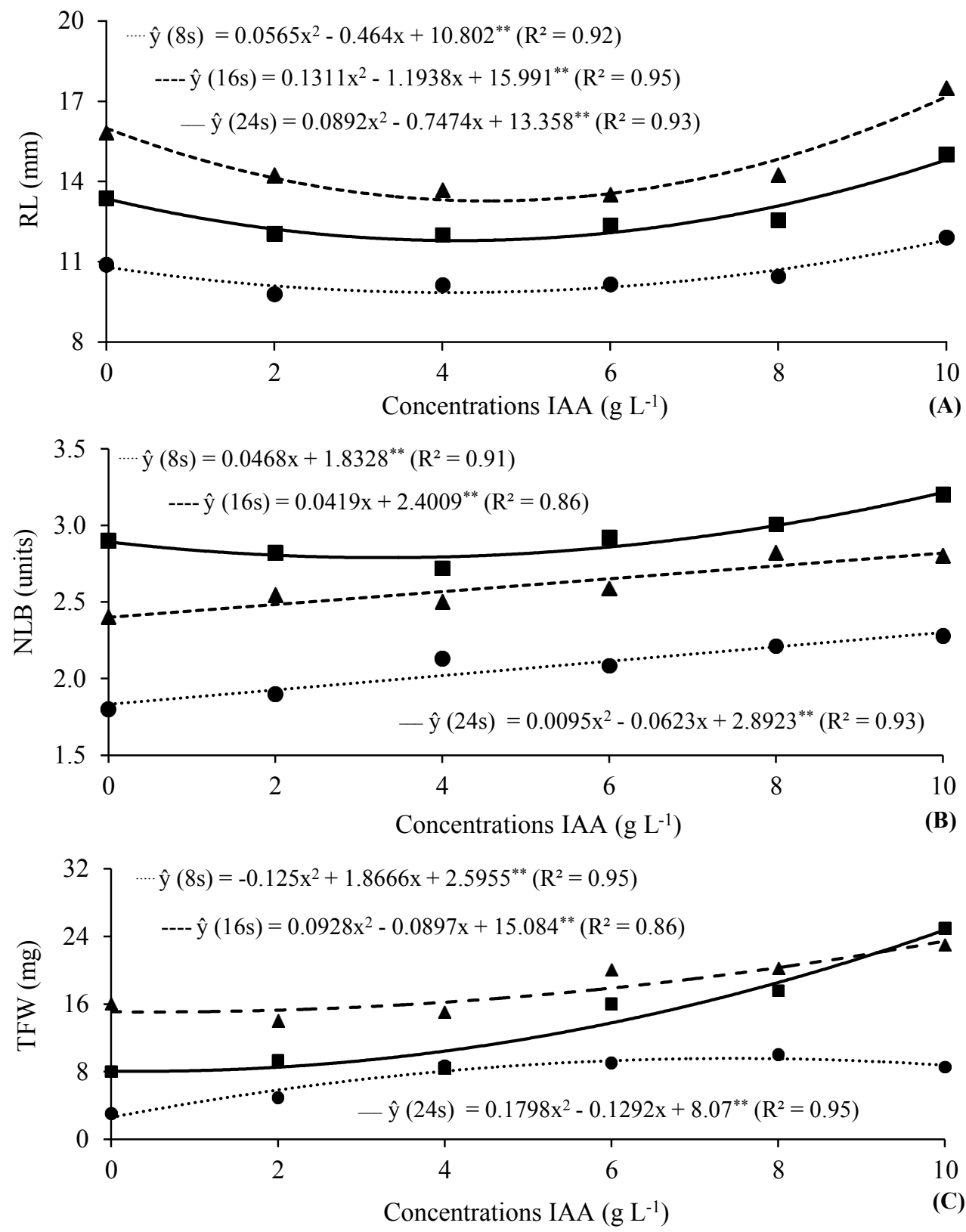

Figure 2. Regression analysis for root length (A), number of leaf buds (B), and total fresh weight (C) of Spondias tuberosa cuttings. 
These similar root lengths found in the treatment without IAA when compared to other treatments can be explained by the easy formation of secondary roots of the species due to its adequate balance of auxins and the activation of mechanisms that use them to induce root formation because of the injury caused by the cut at the base of the plant material for the preparation of the cuttings (HARTMANN; KESTER, 2011).

According to Cruz-Silva, Fanti, ZuffellatoRibas (2013), the use of 1000 and $2000 \mathrm{mg} \mathrm{Kg}^{-1}$ of IBA (powder) increased the cutting root length of Jasminum mesnyi Hance in 6.2 and $5.6 \mathrm{~cm}$, respectively, denoting that the use of less than 1000 $\mathrm{mg} \mathrm{Kg}{ }^{-1}$ is recommended for the improvement of root length of the species. Moura, Salla and Lima (2015) also found higher root length in cuttings of Bougainvillea spectabillis Willd when using NAA at $1 \mathrm{~g} \mathrm{~L}^{-1}$, with increase of $8.2 \mathrm{~cm}$. The highest root length means in $S$. tuberosa were found with the use of $10 \mathrm{~g} \mathrm{~L}^{-1}$ of IAA; the highest length was $17 \mathrm{~mm}$ when using the immersion time of 16 seconds.

The 16-second immersion treatment presented the most promising effect for the percentage of rooted cuttings, with linear growth as a function of the AIA concentrations, but it showed little effect when compared to the control (Figure 2B). The effect of auxins depends on the species; plant age; material collection time; plant genotype; method of use of phytoregulators; environmental conditions, such as temperature, substrate, and air humidity (HARTMANN; KESTER, 2011); and form and type of the auxin applied.

According to Sampaio et al. (2010), the use of IBA $\left(0,0.3,0.6,1.2\right.$, and $\left.2.0 \mathrm{~g} \mathrm{~L}^{-1}\right)$ on cuttings of Aniba canelilla (H.B.K) Mez increased the number of leaf buds in $36 \%$ when using the highest concentration of the phytohormone. However, Tosta et al. (2012) found increases in number of leaf buds in cuttings of a Spondias $s p$. when using $3.5 \mathrm{~g} \mathrm{~L}^{-1}$ of IBA, with estimated number of leaf buds of 2.9 , and decreases of 1.3 per increased unit from this concentration. Although these plants are from the same genus, they have different responses; even with same time of collection and same treatments, $S$. dulcis presented no viable cuttings in adequate number, whereas $S$. tuberosa presented promising results.

The shoot fresh weight of the $S$. tuberosa cuttings presented an increasing effect (Figure 2C), with increases of $38 \%$ and $75 \%$ with use of immersion times of 16 and 24 seconds, respectively, when compared to the control treatment. These results indicate that the use of high concentrations of IAA generates more significant stimuli. However, when using immersion time of 8 seconds and IAA concentration of $7.4 \mathrm{~g} \mathrm{~L}^{-1}$, the shoot fresh weight of the cuttings increased $72 \%$ when compared to the control treatment, presenting a stabilization trend after this concentration, which indicates that use of immersion times below that and higher IAA concentrations are not advantageous for this species. Increases in auxin concentration can stimulate root formation, but from a certain point, these increases can inhibit rooting and reduce cutting survival (ALVARENGA; CARVALHO, 1983).

According to Salibe et al. (2010), the use of IBA concentrations of $3 \mathrm{~g} \mathrm{~L}^{-1}$ with a ten-second immersion time for grapevine rootstocks affected positively shoot fresh weight of the plants, with increases of up to $50 \%$ when compared to the control treatment. This denotes the importance of this hormone for initial development of plants and for their growth in the field.

Cutting propagation was a viable and satisfactory method for the $S$. tuberosa species, regarding the percentage of surviving cuttings, percentage of rooted cuttings, number of leaf buds, and shoot fresh weight. Regarding the number of roots per cutting and root length, despite their low increment, they were significant to increase the adaptive capacity of the plant and to promote better results after 90 days; however, further studies are needed to evaluate these variables, and their effect on the performance of the plant over time. According to Fachinello, Hoffmann and Nachtigal (2005), the IAA auxin is less stable when compared to the IBA and ANA; it is photosensitive and, thus, requires high concentrations to improve rooting in the species evaluated.

The results obtained provide subsidies for the development of further researches related to species of the genus Spondias and show new propagation protocols through stem cuttings of fruit species for commercial plantations in the State of Goiás, Brazil.

\section{CONCLUSIONS}

Vegetative propagation from stem cuttings of Spondias dulcis is not viable to produce seedlings, thus, new studies on this technique for this species are needed.

Vegetative propagation from woody cuttings of $S$. tuberosa is satisfactory, but with low efficiency for improvement and emergence of new shoots and roots; it is more effective when using a concentration of $10 \mathrm{~g} \mathrm{~L}^{-1}$ of indole-3-acetic acid and immersion time in the solution of 16 seconds.

\section{ACKNOWLEDGMENTS}

The authors thank the Brazilian Coordination for the Improvement of Higher Education Personnel (CAPES) for granting scholarships; and the Goiás State University for providing a scholarship through the Researcher Support Program (PROBIP). 


\section{REFERENCES}

ALBUQUERQUE, $H$. et al. Potencial atividade antiulcerogênica da espécie Spondias mombin. Journal of Biology \& Pharmacy and Agricultural Management, v. 10, n. 2, p. 26-29, 2015.

ALMEIDA, J. P. N. et al. Concentrações de AIB e substratos no enraizamento e vigor de estacas lenhosas de cajaraneira. Revista de Ciências Agrárias, v. 60, n. 1, p. 11-18, 2017.

ANDRADE, M. W. et al. Adubos nitrogenados e potássicos na produção de porta-enxertos de umbuzeiro (Spondias tuberosa Arr. Cam.). Revista Caatinga, v. 26, n. 4, p. 117-122, 2013.

ANTUNES, W. C. et al. Spondias tuberosa trees grown in tropical, wet environments are more susceptible to drought than those grown in arid environments. Revista Colombiana de Ciencias Hortícolas, v. 10, n. 1, p. 9-27, 2016

ATROCH, A. L.; CRAVO, M. S.; SANTOS, J. A. Enraizamento de estacas de clones de guaranazeiro tratados com ácido indol-3-butírico (AIB). Revista de Ciências Agrárias, v. 47, n. 1, p. 103-112, 2007.

ALVARENGA, L. R.; CARVALHO, V. D. Uso de substâncias promotoras de enraizamento de estacas frutíferas. Informe Agropecuário, v. 9, n. 101, p. 47 $-55,1983$.

CHALFUN, N. N. J. et al. Enraizamento de estacas dos marmeleiros 'Japonês' e 'Portugal' em diferentes substratos e concentrações de ácido indolbutírico. Ceres, v. 54, n. 311, p. 68-72, 2007.

CRUZ-SILVA, C. T. A.; FANTI, F. P.; ZUFFELLATO-RIBAS, K. C. Propagação vegetativa de jasmim-amarelo (Jasminum mesnyi Hance) via estaquia. Scientia Agraria, v. 14, n. 2, p. 77-82, 2013.

FACHINELLO, J. C.; HOFFMANN, A.; NACHTIGAL, J. C. Propagação de plantas frutíferas. 2. Ed. Brasília, DF: Embrapa Informação Tecnológica, 2005, $221 \mathrm{p}$.

FERREIRA, D. F. Sisvar: a computer statistical analysis system. Ciência e Agrotecnologia, v. 35, n. 6, p. 1039-1042, 2011.

FISCHER, D. D. O. et. al. Efeito do ácido indolbutírico e da cultivar no enraizamento de estacas lenhosas de mirtilo. Revista Brasileira de Fruticultura, v. 30, n. 2, p. 285-289, 2008.

HARTMANN, H. T.; KESTER, D. E. Plant propagation: principles e practices. 8 . Ed. Boston,
MA: Prentice Hall, 2011, 915 p.

LIMA, M. S. S. et al. Caracterização de frutos de genótipos selecionados de umbu-cajazeira (Spondias sp.). Interciencia, v. 40, n. 5, p. 311-316, 2015.

LINS-NETO, E. M. F. et al. Analysis of umbu (Spondias tuberosa Arruda (Anacardiaceae)) in different landscape management regimes: A process of incipient domestication. Environmental Monitoring and Assessment, v. 184, n. 7, p. 44894499, 2012.

LORENZI, H. Frutas brasileiras e exóticas cultivadas: de consumo in natura. 1. Ed. Nova Odessa, SP: Instituto Plantarium, 2006, 357 p.

NACHTIGAL, J. C. Obtenção de porta-enxertos 'Okinawa' e de mudas de pessegueiro (Prunus persica (L.) Batsch) utilizando métodos de propagação vegetativa. 1999. 165 f. Tese (Doutorado em Agronomia) - Faculdade de Ciências Agrárias e Veterinárias, Universidade Estadual Paulista, Jaboticabal, 1999.

MITCHELL, J. D.; DALY, D. C. A revision of Spondias L. (Anacardiaceae) in the Neotropics. PhytoKeys, v. 55, p. 1, p. 1-92, 2015.

MOURA, A. P. C.; SALLA, V. P.; LIMA, D. M. Enraizamento de estacas de Bougainvillea com concentrações de ácido naftalenoacético. Scientia Agraria, v. 16, n. 2, p. 57-61, 2015.

OLIVEIRA, J. A. R. et. al. Tipos de estacas e uso de AIB na propagação vegetativa de fisális. Revista Agroambiente On-line, v. 9, n. 3, p. 342-346, 2015.

OINAM, G. et. al. Adventitious Root formation in ornamental plants: I. general overview and recent successes. Propagation of Ornamental Plants, v. 11, n. 2, p. 78-90, 2011

PAULA, L. A. et. al. Efeito do ácido indolbutírico e raizon no enraizamento de estacas herbáceas e lenhosas de umbuzeiro. Acta Scientiarum. Agronomy, v. 29, n. 3, p. 411-414, 2007.

PEREIRA, M. O. et. al. Enraizamento de estacas de Sequoia sempervirens (D. Don) Endl. em função de concentrações e reaplicações de AIB. Revista Espacios, v. 38, n. 21, p. 1-15, 2017.

PIO, R. et al. Propagação do marmeleiro 'Japonês' por estaquia e alporquia realizadas em diferentes épocas. Ciência e Agrotecnologia, v. 31, n. 2, p. 570-574, 2007.

RADMANN, E. B.; FACHINELLO, J. C.; PETERS, J. A. Efeito de auxinas e condições de cultivo no 
enraizamento in vitro de porta-enxertos de macieira'M-9'. Revista Brasileira de Fruticultura, v. 24, n. 3, p. 624-628, 2002.

REIS, R. V. et al. Estádios de desenvolvimento de mudas de umbuzeiros propagadas por enxertia. Ciência Rural, v. 40, n. 4, p. 787-792, 2010.

RIOS, É. S. et al. Concentrações de ácido indolbutírico, comprimento e época de coleta de estacas, na propagação de umbuzeiro. Revista Caatinga, v. 25, n. 1, p. 52-57, 2012.

ROCHA, L. A. et al. Diferenças foliares morfoanatômicas de quatro espécies da família Anacardiaceae. Caderno de Pesquisa, v. 27, n. 2, p. 35-48, 2015.

SANTOS, C. A. F.; OLIVEIRA, V. R. Inter-relações genéticas entre espécies do gênero Spondias com base em marcadores AFLP. Revista Brasileira de Fruticultura, v. 30, n. 3, p. 731-735, 2008.

SANTOS, H. G. et al. Sistema Brasileiro de Classificação de Solos. 5. ed. Rio de Janeiro, RJ. 2018, 355p.

SANTOS, M. B. D. et al. Caracterização e qualidade de frutos de umbu-cajá (Spondias tuberosa x $S$. mombin) provenientes do recôncavo sul da Bahia. Revista Brasileira de Fruticultura, v. 32, n. 4, p. 1089-1097, 2010.

SAMPAIO, P. D. T. B. et al. Propagação vegetativa por miniestacas de preciosa (Aniba canellila (HBK) MEZ). Acta Amazonica, v. 40, n. 4, p. 687-692, 2010.

SALIBE, A. B. et. al. Enraizamento de estacas do porta-enxerto de videira 'VR 043-43' submetidas a estratificação, ácido indolbutírico e ácido bórico. Bragantia, v. 69 , n. 3, p. 617-622, 2010

SILVA, G. A. et al. Gênero Spondias: aspectos botânicos, composição química e potencial farmacológico. Journal of Biology \& Pharmacy and Agricultural Management, v. 10, n. 1, p. 1-15, 2014.

SOUZA, F. X.; COSTA, J. T. A. Produção de mudas das Spondias cajazeira, cajaraneira, cirigueleira, umbu-cajazeira e umbuzeiro. 1. ed. Fortaleza, CE: Embrapa Agroindústria Tropical, 2010, 133 p.

SOUZA, F. X.; ARAÚJO, C. A. T. Avaliação dos métodos de propagação de algumas Spondias agroindustriais. 1. ed. Fortaleza, CE: Embrapa Agroindústria Tropical, 1999, 4 p.

TAIZ, L.; ZEIGER, E. Fisiologia vegetal. 3.ed. Porto Alegre, RS: Artmed, 2009, 719 p.

TOSTA, M. S. et al. Ácido indolbutírico na propagação vegetativa de cajaraneira (Spondias sp.). Semina: Ciências Agrárias, v. 33, n. 6, p. $2727-$ 2740, 2012

VANZELA, E. S. L. et al. Chemical and sensory characteristics of pulp and peel 'cajámanga' (Spondias cytherea Sonn.) jelly. Ciência e Tecnologia de Alimentos, v. 31, n. 2, p. 398-405, 2011.

VIGNOLO, G. K. et al. Enraizamento de estacas lenhosas de três cultivares de mirtileiro com diferentes concentrações de AIB. Ciência Rural, v. 42 , n. 5 , p. $785-800,2012$. 